\title{
MODELLING OF BIOGENIC VOLATILE ORGANIC COMPOUND EMISSION FOR LITHUANIA*
}

\author{
V. Vèbra, S. Byčenkienè, K. Senuta, and V. Ulevičius \\ Institute of Physics, Savanoriu 231, LT-02300 Vilnius, Lithuania \\ E-mail: ulevicv@ktl.mii.lt
}

Received 18 June 2007; accepted 21 November 2007

\begin{abstract}
We present model estimates of biogenic emissions from forests in Lithuania. The numerical modelling of biogenic volatile organic compounds (BVOCs) monoterpene and isoprene was carried out using three-dimensional (3D) mesoscale meteorological and photochemical atmospheric models. Emission factors, combined with land cover data represented by the appropriate 11 Biogenic Emission Inventory System (BEIS) vegetation categories, along with environmental correction factors were used to derive emission fluxes of isoprene, monoterpene, other VOCs, and NO for Lithuania. Moreover, simulated data have been combined with BEIS data using a Geographic Information System (GIS) to appropriately represent the spatial distribution of BVOCs. Calculations showed that the coniferous trees are the main sources of biogenic emissions. The highest emission fluxes of biogenic VOC are estimated to be in the region of the south-southeastern Lithuania, which has the largest forest coverage in Lithuania and the major part of these forests consist of coniferous forests. The total simulated isoprene emission flux from Lithuania $\left(65281 \mathrm{~km}^{2}\right.$ ) reached $12710 \mathrm{~kg} \mathrm{~h}^{-1}$ in June and $18280 \mathrm{~kg} \mathrm{~h}^{-1}$ in July (approximately $34 \%$ from coniferous forests). On the other hand, monoterpene average emission flux from Lithuania was found to be $4080 \mathrm{~kg} \mathrm{~h}^{-1}$ in June and $5330 \mathrm{~kg} \mathrm{~h}^{-1}$ in July (approximately 50\% from coniferous forests).
\end{abstract}

Keywords: BVOCs, emission, isoprene, monoterpene, numerical modelling, MM5 model

PACS: $92.60 . \mathrm{Sz}$

\section{Introduction}

Biogenic volatile organic compounds (BVOCs) play a prominent role in the chemistry of the atmosphere. BVOCs is a rather loose term for a wide range of compounds, of which only a few are generally of great interest because they are highly reactive and thus may profoundly influence the chemical and physical properties of the atmosphere [1]. The determination of BVOC emission is therefore of utmost importance in regional air chemistry modelling. The most current global BVOC emission inventories are based on model results [2-3]. Using models, it has been estimated that globally the principal natural sources of organic compounds are woods, crops, and shrubs with a combined flux in the range of $1135 \mathrm{TgC} \mathrm{year}^{-1}$, with the majority of this flux attributed to isoprene [2]. Biogenic VOCs include the isoprenoids (isoprene and monoterpenes) as well as alkanes, alkenes, carbonyls, alcohols, esters, ethers, and acids. Emission inventories show isoprene and monoterpenes as the most prominent com-

\footnotetext{
* The report presented at the 37th Lithuanian National Physics Conference, 11-13 June 2007, Vilnius, Lithuania.
}

pounds. Isoprene and monoterpenes as well as their reaction products are involved in tropospheric chemistry, contribute to regional and global changes in the HOradical budget, thereby leading to the production of air pollutants and greenhouse gases, such as ozone, carbon monoxide, and methane, and increasing acidity as well as the production of aerosols. Isoprene is a highly reactive organic compound having an atmospheric lifetime of a few minutes to a few hours [4]. The major sources of isoprene are emissions from deciduous trees, thus over forested areas isoprene mixing ratios can rise up to several ppbv [5-6]. This emphasizes the importance of biogenic emissions, and inventories of BVOC emissions are thus a key issue in atmospheric sciences. During the past few years, reports on the emission pattern and quality of VOC emission from forest and plant species have increased. During the recent decade there have been many studies aimed at quantifying BVOC emissions from forest vegetation [7-11]. Studies of BVOCs have mostly been focused on forests, which are thought to be their dominant global source. The total forestland area covers $31.7 \%$ of Lithuania. During the last 6 years it increased by $1.4 \%$. Coniferous 
stands prevail in Lithuania (58.9\%) followed by softbroadleaves $(36.3 \%)$ and hard-broadleaves (4.8\%).

The aim of this study is to estimate biogenic emissions in Lithuania by modelling. The results presented here provide some insight into the diurnal temperature and species specific emissions (isoprene and monoterpenes) for plant species commonly found in Lithuania.

\section{Methodology}

\subsection{Model description}

A biogenic emissions inventory for the photochemistry domain was derived, using the Biogenic Emissions Inventory System (BEIS), developed at the Environmental Protection Agency (EPA) of the USA [12]. The Biogenic Emissions Inventory System estimates biogenic emissions that are the result of biological activity from land-based vegetative species and nitric oxide emissions which are the result of microbial activity from certain soil types as a function of temperature, sunlight, and vegetation type. The MM5 meteorological model was applied to generate the meteorological fields used with the BEIS3 mode, Biogenic Emissions Land cover Database version 3 (BELD3) land cover database, normalized emissions profiles, and leaf area indexes (LAI) for each land type. The emission fluxes were normalized to standard environmental conditions, i. e. $30^{\circ} \mathrm{C}$ and $1000 \mu \mathrm{mol} \mathrm{m}{ }^{-2} \mathrm{~s}^{-1}$ photosynthetically active radiation (PAR). Since BELD3 database is available only for USA and Canada, the differences in the uncertainty of application can be assessed.

Biogenic emission modelling system - BioModel based on BEIS3 temporal emission computation algorithms was developed for application with the Lithuanian emission inventory (Fig. 1). The algorithms and databases used to estimate the BVOC emissions were incorporated into a geographic information system (GIS) software. BioModel implements OpenGIS specified grid coverage interfaces, involves many GIS typical low-level procedures written in assembly language and using processor multimedia technologies (MMX, SSE), and uses a graphic subsystem to visualize spatial emission data. BioModel consists of inputs to CORINE land cover database, providing information on the different Lithuania land cover data in Geographic Tagged Image File Format (GeoTIFF), MM5 meteorology data in netCDF format and produces spatial-temporal biogenic emissions data, from where the data are directly extracted as standard GRID

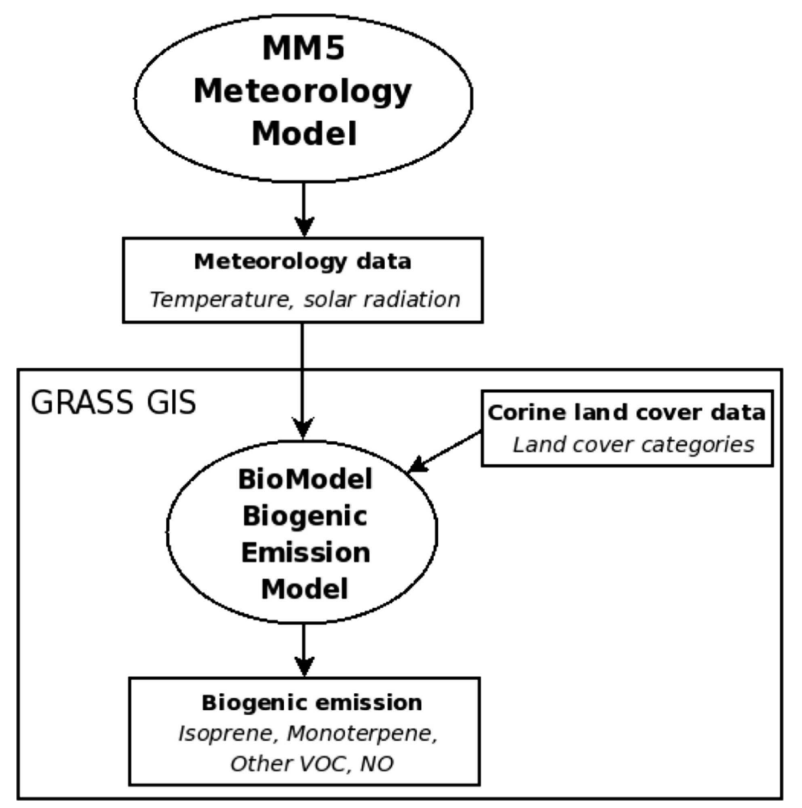

Fig. 1. Diagram of biogenic emission modelling system.

fields, afterwards statistically analysed and stored in the netCDF format.

Static normalized biogenic emission profiles and leaf area index per land use category, obtained from BEIS3 data files, are contained in executable module. BioModel consists of input file in MODELS3 air quality modelling system. Geographic Resources Analysis Support System (GRASS), a raster- and vector-based Geographic Information System image processing system module r.bio.emis, calculating isoprene, monoterpene, other volatile organic compounds and NO temporal emission, was additionally developed. Module r.bio.emis was formatted to input into GRASS software system and supports native GRASS spatial data format. Thus, spatial data can be imported into GRASS geospatial database from various formats and exported to various formats supported by GRASS.

The isoprene emission flux mostly depends on photosynthetically active radiation and environment temperature. BioModel involves a complex canopy model to split photosynthetically active radiation to direct and diffuse beams and compute fractions of leaves that are sunlit and shaded according to pressure, solar radiation, sun altitude, and leaf area index, and finally uses Guenther [13] equation to estimate the light correction factor for isoprene emission flux computation taken from BEIS3.

\subsection{Light and temperature controls on emissions}

Biogenic emission is widely spread and has impact on background atmosphere chemical processes. BVOC 
emission was found to vary from one species to another. For region-scale air quality modelling, biogenic emission researches are concentrated on volatile organic compounds from vegetation and nitrogen oxides from soil. Temperature regulates isoprene [14] and monoterpene [15] synthase activities, thus controlling the synthesis of most isoprenoids.

According to Guenther [16], there are four major factors controlling natural BVOC emissions: landscape average (species-specific) emission potential $\varepsilon$ $\left(\mu \mathrm{g} \mathrm{g}^{-1} \mathrm{~h}^{-1}\right)$, foliar biomass density $D\left(\mathrm{~g} \mathrm{~m}^{-2}\right.$ d.w. dry weight), an environmental correction factor $\gamma$ (nondimensional). Emission fluxes $\left(\mu \mathrm{g} \mathrm{m}^{-2} \mathrm{~h}^{-1}\right)$ can then be modelled by

$$
F=\varepsilon D \gamma
$$

The emission potential and the foliar biomass density are species-specific properties, and they should be assessed individually for each tree genera and subspecies. A non-dimensional environmental correction factor includes the effect of temperature and light conditions.

For appropriate modelling, in-canopy profiles of temperature and radiation must be considered. The emission potential $\varepsilon$ accounts for genetic controls of isoprene and monoterpene production. It represents the emission rate per unit foliar mass for a specific plant species normalized to leaf surface temperature $T_{\mathrm{s}}=$ $30^{\circ} \mathrm{C}$ and photosynthetically active radiation PAR $=$ $1000 \mu \mathrm{mol} \mathrm{m}^{-2} \mathrm{~s}^{-1}$. The environmental correction factor $\gamma$ describes the diurnal variation of the biogenic VOC emissions. Several numerical algorithms have been developed to simulate the effect of light and temperature on isoprene and monoterpene emissions [13, 17-19]. In this work we have adapted the algorithms proposed by Guenther et al. [13], which have been shown to perform extremely well when applied to different vegetation types and environmental conditions (e. g. $[13,20,21])$. According to this approach, the terpene emissions are controlled by the volatilisation of hydrocarbons from storage pools inside the leaf (temperature control), while isoprene is emitted directly after it has been synthesized by the plant (light and temperature control).

\subsection{Environmental correction factor for isoprene and monoterpene}

Isoprene is not stored in plants and emitted in sunlight during photosynthesis. However, monoterpenes can be stored in plants; hence, they are emitted both during the day and night. Basically, one has to distinguish between terpenes, which after biosynthesis will be emitted from leaves more or less immediately and will be stored in corresponding pools prior to emission. If the inner leaf is the location of actual production or storage pools, then the release of terpenes most likely occurs via leaf stomata. The environmental correction factor for isoprene emissions is thus [13]:

$$
\gamma_{\mathrm{ISO}}=C_{T} C_{L},
$$

where $C_{T}$ is the temperature correction and $C_{L}$ is the light correction.

The light correction has the form

$$
C_{L}=\frac{\alpha C_{L 1} L}{\sqrt{1+\alpha^{2} L^{2}}},
$$

where $L$ is the photosynthetically active photon flux density (PPFD), $\mu$ mol photons $\mathrm{m}^{-2} \mathrm{~s}^{-1}, \alpha=0.0027$ and $C_{L 1}=1.066$ are empirical coefficients [16].

The temperature correction is given by Guenther et al. [2]:

$$
C_{T}=\frac{\exp \frac{C_{T 1}\left(T-T_{\mathrm{s}}\right)}{R T_{\mathrm{s}} T}}{C_{T 3}+\exp \frac{C_{T 2}\left(T-T_{M}\right)}{R T_{\mathrm{s}} T}},
$$

where $T$ is the leaf temperature in $\mathrm{K}, T_{\mathrm{S}}$ is the leaf temperature under standard conditions $(303.15 \mathrm{~K}), R$ is the universal gas constant, $C_{T 1}=95000 \mathrm{~J} \mathrm{~mol}^{-1}, C_{T 2}=$ $230000 \mathrm{~J} \mathrm{~mol}^{-1}, C_{T 3}=0.961$, and $T_{M}=314 \mathrm{~K}$ are empirical coefficients given by Guenther [16].

The environmental correction for monoterpene emissions is

$$
\gamma_{\text {TERP }}=\exp \left[\beta\left(T-T_{\mathrm{S}}\right)\right],
$$

where $\beta=0.09 \mathrm{~K}^{-1}$ is an empirical coefficient.

This correction factor is also generally used for other VOCs (oxygenated volatile organic compounds OVOCs), because experimental data on the OVOC emissions are still too scarce to facilitate the development of specific emission algorithms [20,21].

\subsection{NO emission calculation}

This methodology is used from Novak and Pierce [22] and is known commonly as the second version of the Biogenic Emissions Inventory System (BEIS2). BEIS2 estimates NO emissions for forests, agricultural crops, urban trees, and grasslands and calculates a range of emission flux rates based on land use types 

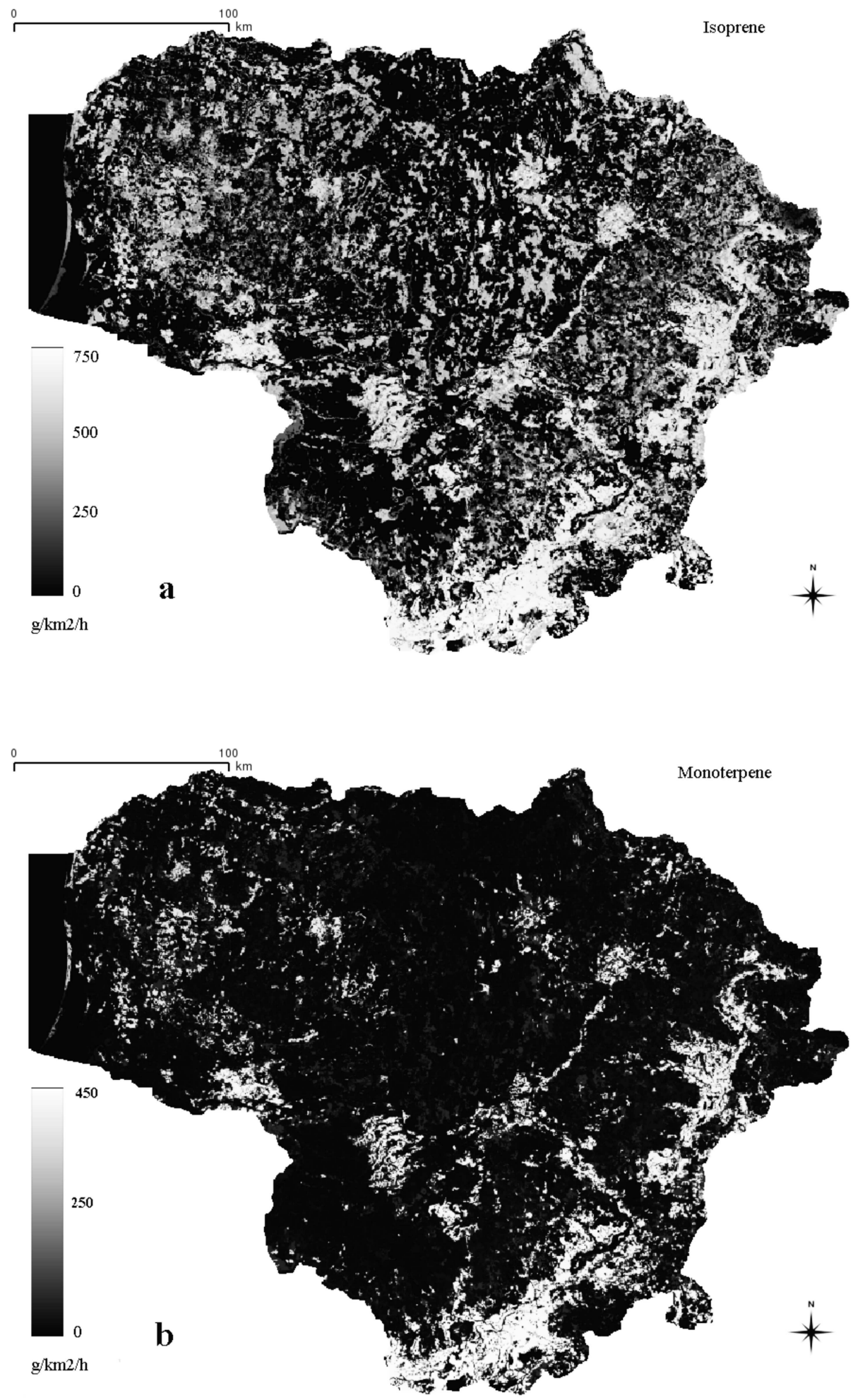

Fig. 2. Biogenic emission distribution in Lithuania for June 2004: (a) isoprene and (b) monoterpene. 

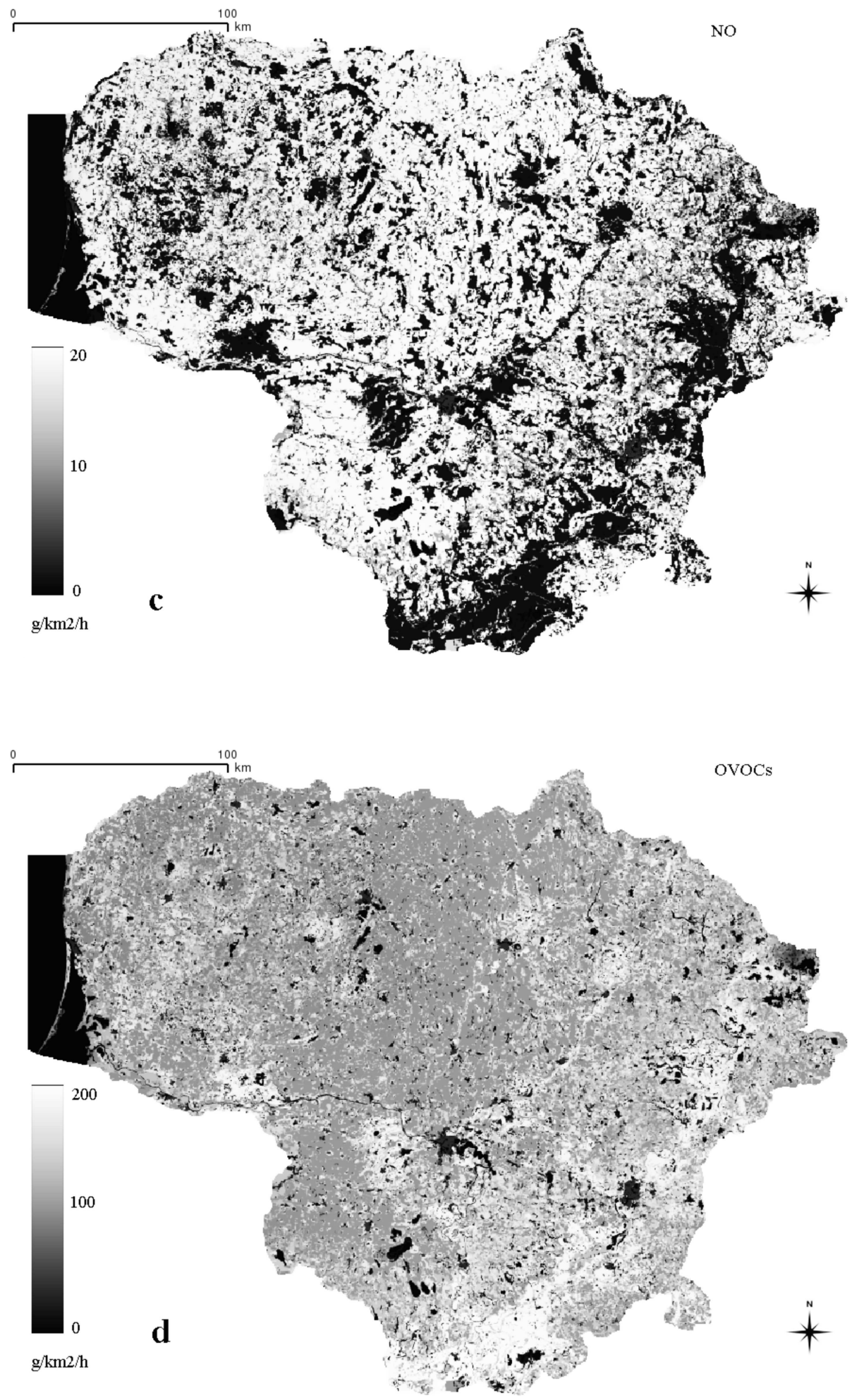

Fig. 2 (continued). Biogenic emission distribution in Lithuania for June 2004: (c) NO and (d) OVOCs. 
Table 1. Empirical coefficients for BEIS2 system.

\begin{tabular}{lc}
\hline \multicolumn{1}{c}{ Emission } & \multicolumn{1}{c}{ Empirical coefficients, $F_{\text {NO }}$} \\
\hline Grassland & $F_{\text {NO G }} \exp (0.04686 T-14.30579)$ \\
Forests & $F_{\text {NO F }} \exp (0.05964 T-18.16535)$ \\
Wetlands & $F_{\text {NO W }} \exp (0.06532 T-19.66061)$ \\
Agriculture & $F_{\text {NO A }} \exp (0.05112 T-15.68248)$ \\
\hline
\end{tabular}

and soil temperature. The BEIS2 calculation for soil NO emissions was performed by Eq. (6) [23]:

$$
F_{\mathrm{NO}}=A \exp \left(0.071 T_{\mathrm{S} 1}\right),
$$

where $A$ is the experimentally derived constant for the land use types of grasslands and pasture, forests, and wetlands, $T_{\mathrm{S} 1}$ is soil temperature, in Celsius.

The BEIS2 biogenic emission model uses more detailed methodology for $\mathrm{NO}$ emission calculation, which was also implemented in BioModel. The parameter $A$ is given in Table 1. Emissions from soils at sub-zero temperatures can be assumed to be zero for inventory purposes.

\section{Results and discussion}

The emission flux of monoterpene, isoprene, and other VOCs mostly depends on photosynthetically active radiation and ambient temperature. NO emission fluxes, which are emitted mostly from agriculture activity, are estimated according to ambient temperature. The highest biogenic emission fluxes in Lithuania were expected during warm season, therefore biogenic emission for June-July 2004 was simulated. Biogenic emission (monoterpene, isoprene, other VOCs, and NO) fluxes attributable to 11 land use categories in Lithuania were simulated using the above model, parameterized and modified using the model input values of the database of biomass, emission flux factors, temperature, and PAR. The model results present the emissions for June-July months of the year 2004. The examples of model results of simulated monthly emissions of BVOCs for June are given in Fig. 2(a-d).

The total simulated isoprene emission flux from Lithuania $\left(65281 \mathrm{~km}^{2}\right)$ reached $12710 \mathrm{~kg} \mathrm{~h}^{-1}$ in June and $18280 \mathrm{~kg} \mathrm{~h}^{-1}$ in July (approximately $34 \%$ from conifer forests). The highest emissions occur in the forested eastern and southern parts of the country with peak emissions of over $1090 \mathrm{~g} \mathrm{~km}^{-2} \mathrm{~h}^{-1}$. The highest isoprene emission fluxes during June (Fig. 2(a)) July were produced by coniferous forests -750 and $520 \mathrm{~g} \mathrm{~km}^{-2} \mathrm{~h}^{-1}$, respectively. Coniferous forests take the area of $7248 \mathrm{~km}^{2}$ (11\% of the Lithuanian area)

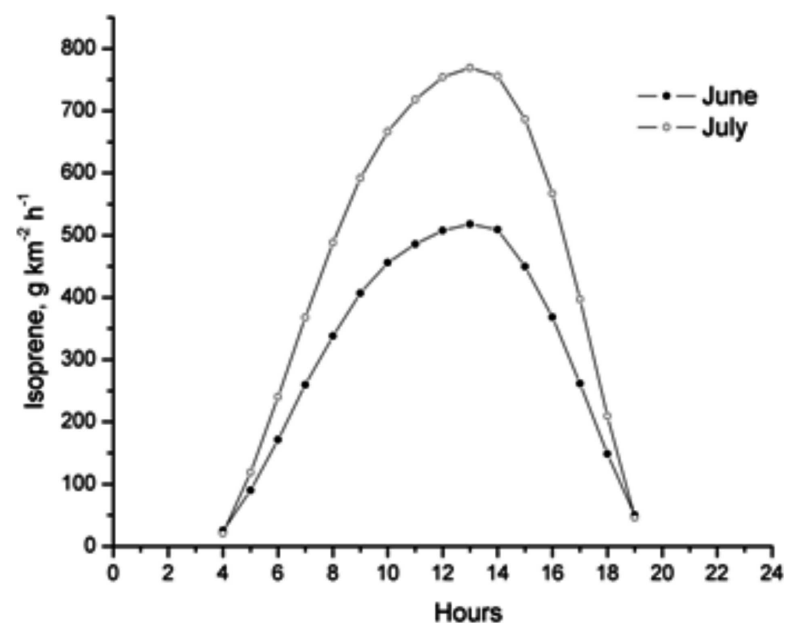

Fig. 3. Variation of isoprene emission flux.

and appear to be the most important isoprene emitters. Other producers of high flux of the isoprene emission were mixed and deciduous forests, which cover $7196 \mathrm{~km}^{2}(11 \%)$ and $4138 \mathrm{~km}^{2}(6.3 \%)$ area of Lithuania and their average emission fluxes were estimated to be 370 and $350 \mathrm{~g} \mathrm{~km}^{-2} \mathrm{~h}^{-1}$ (June), 530 and $500 \mathrm{~g} \mathrm{~km}^{-2} \mathrm{~h}^{-1}$ (July), respectively. In the southeastern part of Lithuania where a high share of all type forests exists, isoprene emissions dominate; in the same part monoterpene emissions prevail as well, as a result of coniferous forests. Thus, all areas in the southern and eastern parts of the country are strong monoterpene emitters with peak emissions of over $560 \mathrm{~g} \mathrm{~km}^{-2} \mathrm{~h}^{-1}$. The highest monoterpene emission fluxes were produced by coniferous forests: average of $280 \mathrm{~g} \mathrm{~km}^{-2} \mathrm{~h}^{-1}$ in June (Fig. 2(b)) and $360 \mathrm{~g} \mathrm{~km}^{-2} \mathrm{~h}^{-1}$ in July. The total simulated monoterpene average emission flux from Lithuania was found to be $4080 \mathrm{~kg} \mathrm{~h}^{-1}$ in June and $5330 \mathrm{~kg} \mathrm{~h}^{-1}$ in July (approximately 50\% from coniferous forests). Although coniferous forests produced highest OVOC emission fluxes (average of $115 \mathrm{~g} \mathrm{~km}^{-2} \mathrm{~h}^{-1}$ in June, Fig. 2(d), and $150 \mathrm{~g} \mathrm{~km}^{-2} \mathrm{~h}^{-1}$ in July), the total highest average emission flux was produced by dry crop, which takes $22233 \mathrm{~km}^{2}$ (34\%) area in Lithuania, i.e. $1940 \mathrm{~kg} \mathrm{~h}^{-1}$ in June and $2510 \mathrm{~kg} \mathrm{~h}^{-1}$ in July. The total average OVOC emission flux from Lithuania was $5760 \mathrm{~kg} \mathrm{~h}^{-1}$ in June and $7480 \mathrm{~kg} \mathrm{~h}^{-1}$ in July (approximately 33\% from dry crop). Moreover, it was found that the highest average NO emission fluxes were produced by dry crop (agriculture activity): $115 \mathrm{~g} \mathrm{~km}^{-2} \mathrm{~h}^{-1}$ in June and $150 \mathrm{~g} \mathrm{~km}^{-2} \mathrm{~h}^{-1}$ in July. The total average NO emission flux from Lithuania was found to be $660 \mathrm{~kg} \mathrm{~h}^{-1}$ in June (Fig. 2(c)) and $750 \mathrm{~kg} \mathrm{~h}^{-1}$ in July (approximately 50\% from dry crop). In a word, the biogenic VOC emissions in Lithuania are not very high since the country is 


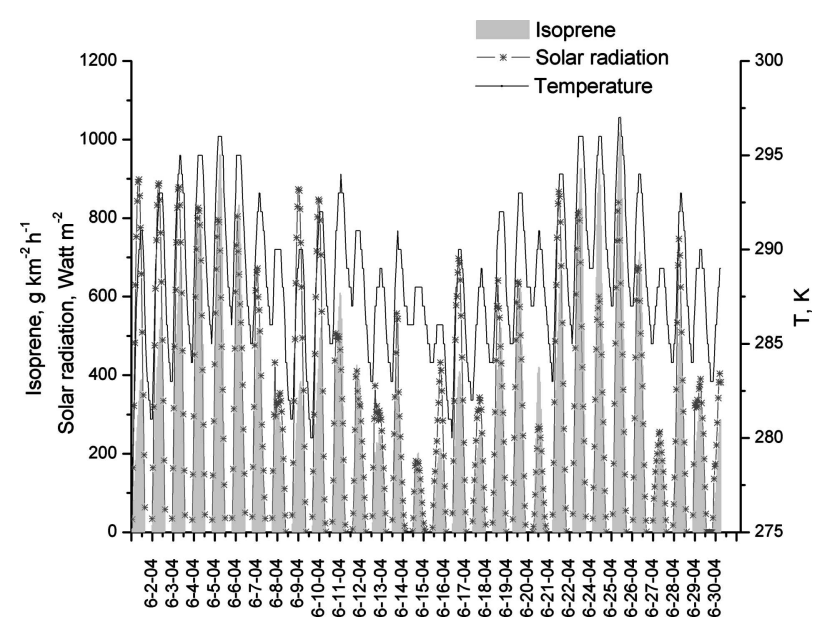

(a)

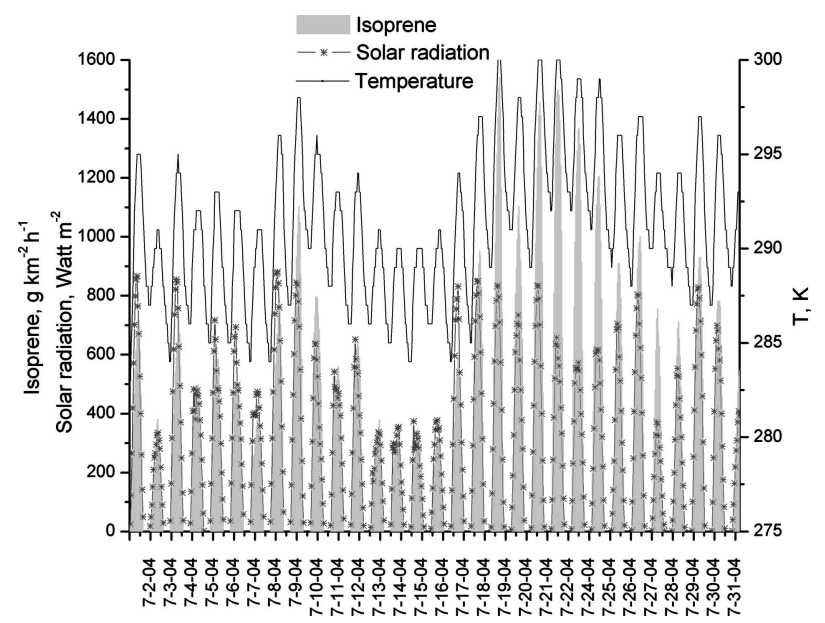

(b)

Fig. 4. Time series of the isoprene emission flux, solar radiation, and temperature over Lithuania:(a) June, (b) July.

located in the zone where the average air temperature and solar radiation are low.

Figure 3 depicts the time series (discontinuous hourly measurements) of isoprene for the Lithuanian domain during the period June-July, 2004. Isoprene emissions are caused by the photosynthesis flux, which maximizes at noon and ceases at night (simulated night value was 0 ).

The simulated isoprene emission showed a typical

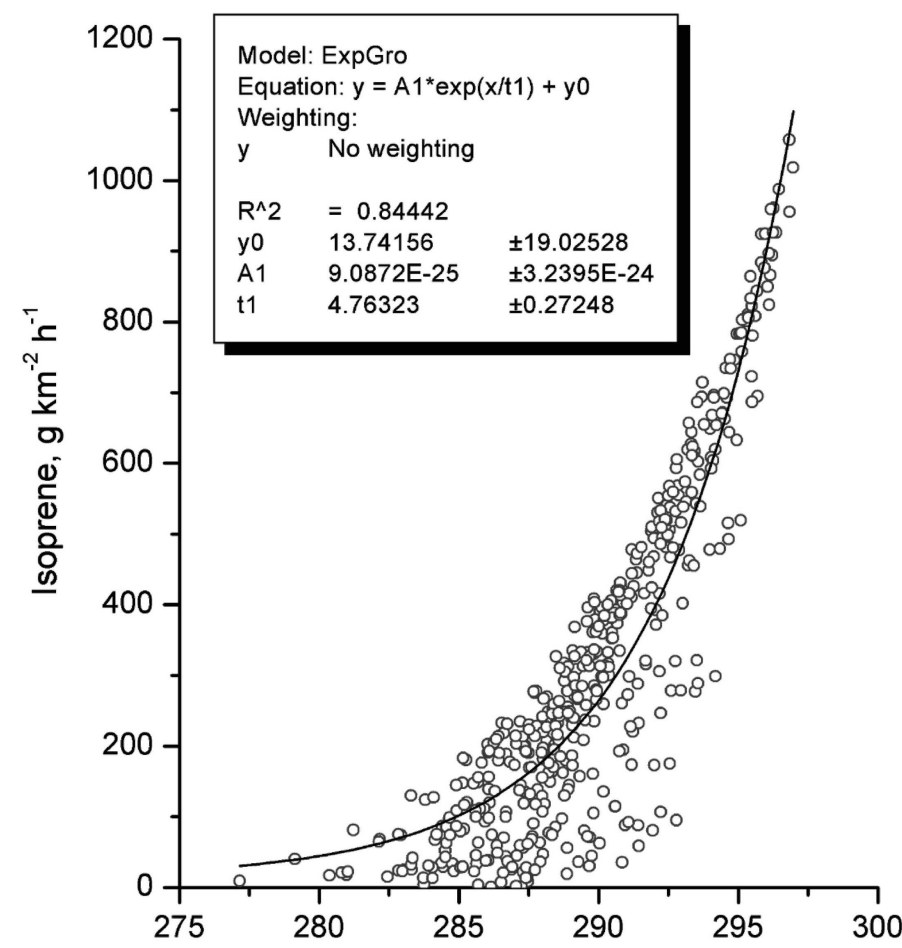

variation with a light- and temperature-dependent increase in the morning and a decline of the emission flux during the night (Fig. 3). Maximum daily values of $500 \mathrm{~g} \mathrm{~km}^{-2} \mathrm{~h}^{-1}$ (June) and $750 \mathrm{~g} \mathrm{~km}^{-2} \mathrm{~h}^{-1}$ (July) were reached by noon.

The impact of light intensity and temperature on isoprene emissions was examined (Fig. 4). The variation of isoprene emissions closely follows the temperature variability, and daily emissions reflect the great

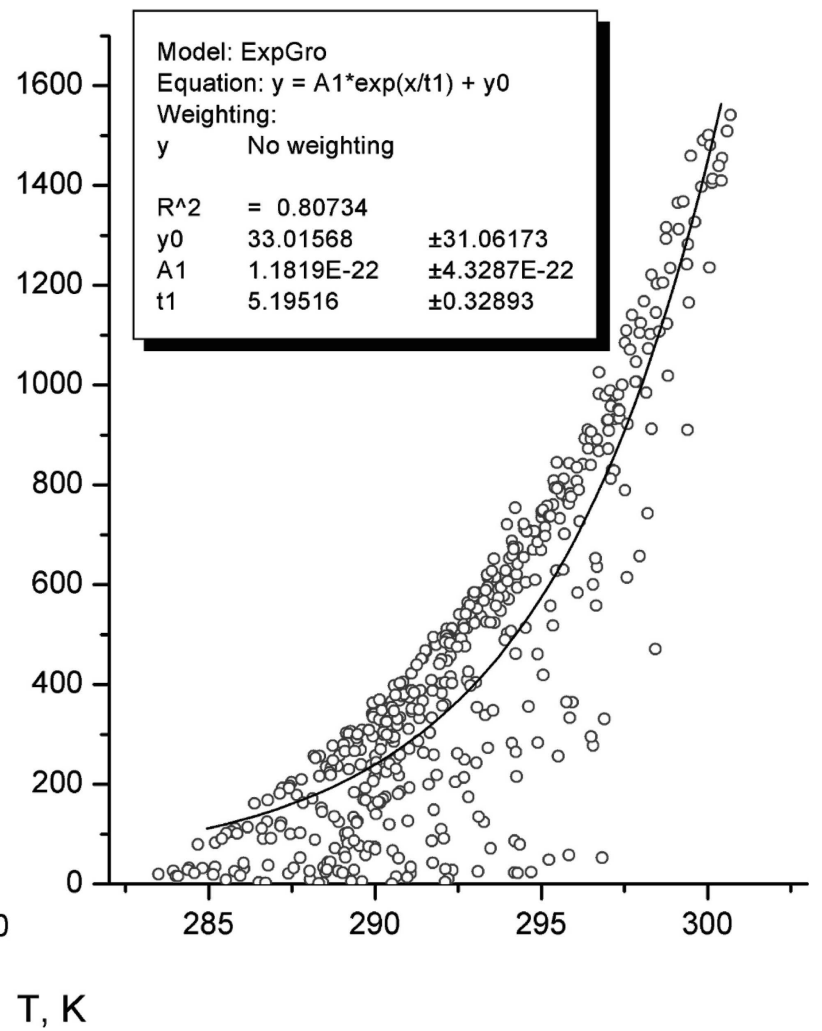

(b)

(a)

Fig. 5. Dependence of isoprene emission fluxes on temperature over Lithuania: (a) June, (b) July. 
sensitivity of isoprene to the environmental conditions (Eqs. (3), (4)). The temperature and solar radiation dependence of isoprene emissions is reflected in diurnal emission patterns. Isoprene levels demonstrated an exponential increase with temperature (Fig. 4). The isoprene emission is also strongly dependent on temperature, increasing exponentially up to a maximum emission at approximately $24^{\circ} \mathrm{C}$ (June) and $27^{\circ} \mathrm{C}$ (July) (Fig. 5(a,b)). The regression analysis revealed significant correlations at a $99 \%$ confidence level between temperature and isoprene emission fluxes $(r=0.78$, $N=1412$, June; $r=0.84, N=1466$, July). Moreover, isoprene emission fluxes respond very rapidly to changes in light intensity as well (Fig. 4).

\section{Conclusions}

A biogenic emission modelling system for Lithuania has been created using emission algorithms of Guenther et al. [13] with some modifications and land cover data.

The highest isoprene emission fluxes during JuneJuly were produced by coniferous forests -520 and $750 \mathrm{~g} \mathrm{~km}^{-2} \mathrm{~h}^{-1}$, respectively. Coniferous forests take an area of $7248 \mathrm{~km}^{2}$ (11\% of the Lithuanian area) and appear to be the most important isoprene emitters. Other producers of high flux isoprene emission were mixed and deciduous forests, which cover $7196 \mathrm{~km}^{2}$ (11\%) and $4138 \mathrm{~km}^{2}(6.3 \%)$ area of Lithuania and their average emission fluxes were estimated to be 370 and $350 \mathrm{~g} \mathrm{~km}^{-2} \mathrm{~h}^{-1}$ (June), 530 and $500 \mathrm{~g} \mathrm{~km}^{-2} \mathrm{~h}^{-1}$ (July), respectively. The highest monoterpene emission fluxes were produced by conifer forests: average of $280 \mathrm{~g} \mathrm{~km}^{-2} \mathrm{~h}^{-1}$ in June and $360 \mathrm{~g} \mathrm{~km}^{-2} \mathrm{~h}^{-1}$ in July.

The impact of light intensity and temperature on isoprene emissions was investigated. The temperature and solar radiation dependence of isoprene emissions is reflected in diurnal emissions patterns. Isoprene levels demonstrated an exponential increase with the temperature.

In future we will develop emission algorithms for each monoterpene species emitted by the forest trees at various phases of the growing season. This will allow the creation of specific compound emission inventories that are important for the future assessments of the aerosol-producing capacity of biogenic VOCs and the role of forests as regulators of the atmospheric chemical composition.

\section{Acknowledgement}

This research was supported by the Agency for International Science and Technology Development Programmes in Lithuania under EUREKA WEBAIR project. The authors are grateful for this assistance.

\section{References}

[1] R. Atkinson and J. Arey, Gas-phase tropospheric chemistry of biogenic volatile organic compounds: A review, Atmos. Environ. 37, S197-S219 (2003).

[2] A. Guenther, C.N. Hewitt, D. Erickson, R. Fall, C. Geron, T. Graedel, P. Harley, L. Klinger, M. Lerdau, W. McKay, T. Pierce, B. Scholes, R. Steinbrecher, R. Tallamraju, J. Taylor, and P. Zimmerman, A global model of natural volatile organic compound emissions, J. Geophys. Res. 100(D5), 8873-8892 (1995).

[3] A. Guenther, T. Karl, P. Harley, C. Wiedinmyer, P.I. Palmer, and C. Geron, Estimates of global terrestrial isoprene emissions using MEGAN (Model of Emissions of Gases and Aerosols from Nature), Atmos. Chem. Phys. 6, 3181-3210 (2006).

[4] L.B. Otter, A. Guenther, J. Greenberg, and M.C. Scholes, Seasonal and spatial variations in biogenic hydrocarbon emissions from south African savannas and woodlands, Atmos. Environ. 36, 4265-4275 (2002).

[5] E.C. Apel, D.D. Riemer, A. Hills, W. Baugh, J. Orlando, I. Faloona, D. Tan, W. Brune, B. Lamb, H. Westberg, M.A. Carroll, T.Thornberry, and C.D. Geron, Measurement and interpretation of isoprene fluxes and isoprene, methacrolein, and methyl vinyl ketone mixing ratios at the PROPHET site during the 1998 Intensive, J. Geophys. Res. 107(D3), doi:10.1029/2000JD000225 (2002).

[6] H.J. Rinne, A. Guenther, and J.P. Greenberg, Isoprene and monoterpene fluxes measured above Amazonian rainforestand their dependence on light and temperature, Atmos. Environ. 36, 2421-2426 (2002).

[7] D.R. Bowling, A.A. Turnipseed, A.C. Delany, D.D. Baldocchi, J.P. Greenberg, and R.K. Monson, The use of relaxed eddy accumulation to measure biosphere-atmosphere exchange of isoprene and other biologicaltrace gases, Oecologia 116, 306-315 (1998).

[8] J. Fuentes, M. Lerdau, R. Atkinson, D. Baldocchi, J. Bottenheim, P. Ciccioli, B. Lamb, C. Geron, L. Gu, A. Guenther, T. Sharkey, and W. Stockwell, Biogenic hydrocarbons in the atmospheric boundary layer: A review, Bull. Am. Meteor. Soc. 81, 1537-1575 (2000).

[9] A.H. Goldstein, M.L. Goulden, W.J. Munger, S.C. Wofsy, and C.D Geron, Seasonal course of isoprene emissions from a midlatitude deciduous forest, J. Geophys. Res. 103(D23), 31045-31056 (1998).

[10] J.G. Isebrands, A.B. Guenther, P. Harley, D. Helmig, L. Klinger, L. Vierling, P. Zimmerman, and C. Geron, 
Volatile organic compound emission rates from mixed deciduous and coniferous forests in Northern Wisconsin, USA, Atmos. Environ. 33, 2527-2536 (1999).

[11] U. Kuhn, S. Rottenberger, T. Biesenthal, A. Wolf, G. Schebeske, P. Ciccioli, E. Brancaleoni, M. Frattoni, T. M. Tavares, and J. Kesselmeier, Isoprene and monoterpene emissions of Amazonian tree species during the wet season: Direct and indirect investigations on controlling environmental functions, J. Geophys. Res.- Atmos. 107(D20), 8071, doi:10.1029/2001JD000978 (2002).

[12] BEIS3 Version 0.9, United States Environmental Protection Agency, http://www.epa.gov/ AMD/biogen.html.

[13] A.B. Guenther, P.R. Zimmerman, P.C. Harley, R.K. Monson, and R. Fall, Isoprene and monoterpene emission rate variability - model evaluations and sensitivity analyses, J. Geophys. Res. - Atmos. 98(D7), 12609-12617 (1993).

[14] R.K. Monson, C.H. Jaeger, W.W. Adams, E.M. Driggers, G.M. Silver, and R. Fall, Relationships among isoprene emission rate, photosynthesis, and isoprene synthase activity as influenced by temperature. Plant Physiol. 98, 1175-1180 (1992).

[15] R.J. Fischbach, W. Zimmer, and J.P. Schnitzler, Isolation and functional analysis of a cDNA encoding a myrcene synthase from holm oak (Quercus ilex L.), Eur. J. Biochem. 268, 5633-5638 (2001).

[16] A. Guenther, Seasonal and spatial variations in natural volatile organic compound emissions, Ecol. Appl. 7,
34-45 (1997).

[17] B. Lamb, D. Gay, H. Westberg, and T. Pierce, A biogenic hydrocarbon emission inventory for the U.S.A. using a simple forest canopy model, Atmos. Environ. 27A, 1673-1690 (1993).

[18] A. Guenther, R. Monson, and R. Fall, Isoprene and monoterpene emission rate variability: Observations with eucalyptus and emission rate algorithm development, J. Geophys. Res. 26A, 10799-10808 (1991).

[19] B. Lamb, E. Allwine, S. Dilts, H. Westberg, T. Pierce, C. Geron, D. Baldocchi, A. Guenther, L. Klinger, P. Harley, and P. Zimmerman, Evaluation of forest canopy models for estimating isoprene emissions, J. Geophys. Res. 101(D17), 22787-22798 (1996).

[20] A. Guenther, P. Zimmerman, and M. Wildermuth, Natural volatile organic compound emission rate estimates for U.S. woodland landscapes, Atmos. Environ. 28, 1197-1210 (1994).

[21] D. Simpson, W. Winiwarter, G. Borjesson, S. Cinderby, A. Ferreiro, A. Guenther, C.N. Hewitt, R. Janson, M.A.K. Khalil, S. Owen, T.E. Pierce, H. Puxbaum, M. Shearer, U. Skiba, R. Steinbrecher, L. Tarrason, and M.G. Oquist, Inventorying emissions from nature in Europe, J. Geophys. Res.- Atmos. 104(D7), 8113-8152 (1999).

[22] J. Novak and T. Pierce, Natural emissions of oxidant precursors. Water Air Soil Poll. 67, 57-77 (1993).

[23] E. Williams, A. Guenther, and F. Fehsenfeld, An inventory of nitric oxide emissions from soils in the United States, J. Geophys. Res. 97, 7511-7519 (1992).

\title{
BIOGENINIU LAKIŲJŲ ORGANINIŲ JUNGINIŲ EMISIJOS LIETUVOJE MODELIAVIMAS
}

\author{
V. Vèbra, S. Byčenkienè, K. Senuta, V. Ulevičius \\ Fizikos institutas, Vilnius, Lietuva
}

\section{Santrauka}

Pagrindinis natūralus lakiụjų biogeninių organinių junginių šaltinis yra miškai. Lakiųjų biogeninių organinių junginių izopreno ir monoterpeno erdvinis pasiskirstymas Lietuvoje 2004 m. birželioliepos mėnesiais ivvertintas pritaikius Guenther modelị [13] su tam tikrais pakeitimais dèl vietinių ypatumų. Biogeninių organinių jun- ginių erdvinei analizei atlikti buvo panaudoti emisijos koeficientai, žemès reljefas, BEIS augalų klasifikavimas pagal jų rūši ir kiti vietiniai aplinkos parametrai. Nustatyta, kad biogeniniu organiniu junginiu emisijos pasiskirstymas Lietuvoje netolygus: stebimas jos padidejimas pietu-pietvakarių kryptimi ir ryškus sumažèjimas Vilniaus bei Kauno apylinkèse. 